\title{
Note on the germination of Vochysia tucanorum seeds treated with growth regulators
}

\author{
BRUNO F. PEREIRA ${ }^{1}$, EDSON SIMÃO ${ }^{2}$, JOÃO B. TERRA FILHO ${ }^{1}$, JEAN C. CARDOSO ${ }^{3,4}$ and \\ VICTOR J. M. CARDOSO ${ }^{1}$
}

(received: August 26, 2009; accepted: April 7, 2011)

\begin{abstract}
Note on the germination of Vochysia tucanorum seeds treated with growth regulators). The aim of this work was to evaluate the germination response of Vochysia tucanorum Mart. seeds treated with $\mathrm{GA}_{3}$ and CEPA and germinated under white light or darkness. Newly collected seeds from a Cerrado area were stored for 14 days at two temperatures $\left(25^{\circ} \mathrm{C}\right.$ \pm 2 and $7{ }^{\circ} \mathrm{C} \pm 1$ ). After the storage period the seeds were pre-treated with distilled water (control), gibberellic acid $\left(\mathrm{GA}_{3}\right)$, 2-chloroethylphosphonic acid (CEPA) and a mixture of $\mathrm{GA}_{3}+\mathrm{CEPA}$. Following this, the seeds were sown in Petri dishes on filter paper moistened with distilled water and germinated in either darkness or white light. The results suggest that seeds are non-photoblastic and non-dormant, however a photoblastic behavior emerges when the seeds were previously stored at low temperature and imbibed in CEPA and $\mathrm{GA}_{3}$ solutions. In general, there is no difference between the $7{ }^{\circ} \mathrm{C}$ and $25^{\circ} \mathrm{C}$ storage temperatures. The germination of seeds pre-treated with CEPA and CEPA $+\mathrm{GA}_{3}$ under white light was faster as compared to the distilled water control, and the effect of the CEPA $+\mathrm{GA}_{3}$ mixture was more pronounced than CEPA alone. Thus, the germination rate of $V$. tucanorum seeds can be improved by treatment with CEPA or CEPA $+\mathrm{GA}_{3}$ under white light.
\end{abstract}

Key words - CEPA, ethylene, gibberellin, light, temperature

RESUMO - (Nota sobre a germinação de sementes de Vochysia tucanorum tratadas com reguladores vegetais). O objetivo deste trabalho foi avaliar a resposta germinativa sob luz branca e escuro de sementes de Vochysia tucanorum Mart. tratadas com $\mathrm{GA}_{3}$ e CEPA. Sementes recém-coletadas de uma área de Cerrado foram armazenadas durante 14 dias em duas temperaturas $\left(25 \pm 2{ }^{\circ} \mathrm{C} \mathrm{e} 7 \pm 1{ }^{\circ} \mathrm{C}\right)$. Após o período de armazenamento, as sementes foram pré-tratadas com água destilada (controle), ácido giberélico $\left(\mathrm{GA}_{3}\right)$, ácido 2-cloroetilfosfônico (CEPA) e uma mistura de $\mathrm{GA}_{3}+\mathrm{CEPA}$; em seguida, as sementes foram semeadas em placas de Petri sobre papel filtro umedecido com água destilada e colocadas para germinar em escuro e sob luz branca. Os resultados sugerem que as sementes não são fotoblásticas nem dormentes, no entanto um comportamento fotoblástico emerge quando as sementes foram previamente armazenadas em baixa temperatura e embebidas em soluções de $\mathrm{GA}_{3}$ e CEPA. Em geral, não houve diferença entre as temperaturas de armazenamento de $7{ }^{\circ} \mathrm{Ce} 25^{\circ} \mathrm{C}$. A germinação sob luz branca de sementes pré-tratadas com $\mathrm{CEPA}+\mathrm{GA}_{3}$ e CEPA foi antecipada, em comparação com o controle de água destilada, sendo que o efeito da mistura CEPA $+\mathrm{GA}_{3}$ foi mais pronunciado do que o de CEPA sozinho. Assim, a taxa de germinação de sementes de $V$. tucanorum, sob luz branca, pode ser melhorada pela embebição das mesmas em soluções de CEPA ou de CEPA $+\mathrm{GA}_{3}$.

Palavras chave - CEPA, etileno, giberelina, luz, temperatura

\section{Introduction}

The Cerrado harbors as many as 6,500 species of vascular plants distributed in vegetal formations

1. Universidade Estadual Paulista, Instituto de Biociências, Departamento de Botânica, Av.24-A, 1515, Bela Vista, 13506-900 Rio Claro, SP, Brazil.

2. Universidade Estadual Paulista, Instituto de Biociências, Departamento de Botânica, Programa de Pós-Graduação em Botânica, Av.24-A, 1515, Bela Vista, 13506-900 Rio Claro, SP, Brazil.

3. Universidade de São Paulo, Centro de Energia Nuclear na Agricultura, Programa de Pós-Graduação em Ciências, Av. Centenário, 303, 13400-970 Piracicaba, SP, Brazil.

4. Corresponding author: jeancardosoctv@gmail.com of variable aspects and physiognomies, and it is characterized by a high biodiversity as compared to other savannah-like biomes. Researchers estimate that about $50 \%$ of the original Cerrado landscape is already altered due to human activities (Mendonça et al. 1998, Mittermaier et al. 1999), and less than $2 \%$ of its area is protected in national parks and conservation reserves. The Cerrado flora is still relatively poorly understood, and requires intense study aimed at the regeneration of degraded areas (Nascimento \& Saddi 1992). In such a context, the regeneration strategies of cerrado species depend to a large extent on germination, which in turn is influenced by physiological characteristics of the seeds such as dormancy. Dormancy is characterized by the 
failure of a viable seed to germinate even when it is exposed to favorable water, temperature and atmospheric conditions. Physiological dormancy is a type of seed dormancy caused by a physiological inhibiting mechanism of the embryo that prevents radicle emergence, and it can be overcome by chemicals, including ethylene and gibberellins (Baskin \& Baskin 2001).

Trials with exogenous hormones have shown that the dormancy of many seeds can be overcome by treatments with ethylene and gibberelins (GAs) which have also been reported to control germination, although GAs appear to play a major role in regulating the process (Matilla \& Matilla-Vasquez 2008). In general, an increase of the ethylene biosynthesis is accompanied by a transient peak of active gibberellins within the seeds (Kucera et al. 2005). Pereira et al. (2004a) reported a significant increase of the germination (seedling emergence) of araticum (Annona crassiflora Mart.) seeds imbibed in gibberellic acid $\left(\mathrm{GA}_{3}\right)$ in concentrations ranging from 500 to $1,000 \mathrm{mg} \mathrm{L}^{-1}$. Bernardes et al. (2008) estimated a $\mathrm{GA}_{3}$ concentration of $345 \mathrm{mg} \mathrm{L}^{-1}$ as optimum for the emergence of pequi (Caryocar brasiliense Cambess.), whereas Pereira et al. (2004b) reported that $\mathrm{GA}_{3}$ concentrations ranging from 125 to $500 \mathrm{mg} \mathrm{L}^{-1}$ provided the highest effect in overcoming seed dormancy in that species. Application of exogenous ethylene or ethylene-generating substances such as CEPA (2-chloroethylphosphonic acid) promotes the germination of many plant species (Abeles 1986, Moraes \& Lopes 1998).

The response of seeds to growth substances appears to depend on environmental factors, such as light and temperature, as well as on endogenous factors, such as the dormancy status of the seed. These factors can exhibit a complex interaction on the germination process, as exemplified by lettuce seeds (Burdett \& Vidaver (1971)). In Arabidopsis thaliana (L.) Heynh. and Sisymbrium officinale (L.) Scop. it was also reported that light affects seed germination through a chain of events leading to gibberellin biosynthesis, and that light seems to enhance the sensitivity of the seeds to that hormone (Hilhorst \& Karssen 1988).

Vochysia tucanorum Mart. (Vochysiaceae) is a tree widely distributed in Brazil, from Bahia to Paraná and from Rio de Janeiro to Mato Grosso do Sul, occurring in different types of forests, mostly in the Cerrado domain and in environments with intermediate radiation levels (Barbosa et al. 1999). The species is considered as early secondary in mesophytic semi-deciduous forest in São Paulo State (Gandolfi et al. 1995). The seeds present a lateral wing consisting of interlaced trichomes inserted in the coat. There is a lag of approximately 13 days between sowing and the beginning of germination, whereas the removal of the seed coat reduces this time to half. The optimum germination is at a temperature of $25^{\circ} \mathrm{C}$ (Barbosa et al. 1999).

The objective of this study was to evaluate the germination response of Vochysia tucanorum seeds treated with $\mathrm{GA}_{3}$ and CEPA, in order to search for evidence about the role played by gibberellins and ethylene on the control of the germination process of this species, and to conduct searches for factors affecting that response.

\section{Material and methods}

Mature and dry fruits of Vochysia tucanorum were collected in October, 2008 from a population growing in a cerrado area $\left(22^{\circ} 15^{\prime} 16^{\prime \prime} \mathrm{S}\right.$ and $\left.47^{\circ} 08^{\prime} 12^{\prime \prime} \mathrm{W}\right)$ at Mogi Guaçu, São Paulo State. Once collected, the seeds were extracted from the fruits manually and the visually damaged ones were discarded. The seeds were randomly divided into two groups of 640 seeds each, which had been stored for 14 days in a climatized room at $25^{\circ} \mathrm{C} \pm 2$ and in a refrigerator at $7{ }^{\circ} \mathrm{C} \pm 1$, respectively. After the storage period, each main group was divided into four equally sized subgroups of 160 seeds each, which were subjected to the following treatments: gibberellic acid $\left(\mathrm{GA}_{3}\right) \quad 0.6 \mathrm{mmol} \mathrm{L}^{-1} ; 2$ 2-chloroethylphosphonic acid (CEPA, Union Carbide) $0.7 \mathrm{mmol} \mathrm{L}^{-1}$; and a $\mathrm{GA}_{3}+\mathrm{CEPA}$ mixture at a final concentration of $0.6 \mathrm{mmol} \mathrm{L}^{-1}$ and $0.7 \mathrm{mmol} \mathrm{L}^{-1}$, respectively. The seeds were kept immersed in the solutions for $24 \mathrm{~h}$, whereas a sample (control) was immersed in distilled water for the same period.

After the treatments, the seeds were sowed in $11 \times 11 \times 3.5 \mathrm{~cm}$ crystal polystyrene germination boxes (gerboxes) on two sheets of thick filter paper moistened with $10 \mathrm{~mL}$ of distilled water. The gerboxes were placed randomly in a climatized room at $25^{\circ} \mathrm{C} \pm 2$, under white light (irradiance of $40 \mu \mathrm{mol} \mathrm{m}^{-2} \mathrm{~s}^{-1}$ ) and darkness (black gerbox). Four replicates of 20 seeds each were used per treatment. The germination (radicle protrusion) was examined weekly for 21 days, with the germinated seeds being counted and discarded. The seeds kept in darkness were handled under a dim green safety light. The germinability (final germination percentage) data were transformed to the respective angular values $(\operatorname{arcsen} \sqrt{ } \%)$ and submitted to a factorial ANOVA. The post-hoc Tukey test $(\alpha=0.05)$ was used to compare the treatments.

\section{Results and discussion}

Vochysia tucanorum seeds are able to germinate under both white light and in darkness, and the relatively high germinability ( $c a .83$ to $100 \%$ ) (table 1 ) suggests that the seeds can be regarded as non-dormant. These 
results are in agreement with Barbosa et al. (1999), who reported that $V$. tucanorum seeds germinated better (around $93 \%$ ) at a constant temperature of $25^{\circ} \mathrm{C}$, either under continuous light or darkness, showing that the seeds are not photoblastic at this temperature. Furthermore, studies on the initial growth of $V$. tucanorum seedlings suggest that the species is shade-tolerant (Barbosa et al. 1999). In agreement with this, Costa \& Araújo (2001) compared the distribution of $V$. tucanorum in cerrado and in cerradão, and specimens were found only in the latter, where the irradiance was lower than in the cerrado. An interaction was observed among temperature, pretreatment, light, and chemicals (table 1). Regardless of the storage temperature, the germination of V.tucanorum seeds in distilled water remained indifferent to light; however a photoblastic behavior emerged when the seeds had been previously stored at low temperature $\left(7^{\circ} \mathrm{C}\right)$ and soaked in CEPA and $\mathrm{GA}_{3}$ solutions (table 1). The germination percentage determined after three weeks was higher under white light than in darkness for seeds previously stored at $25^{\circ} \mathrm{C}$ and imbibed in a $\mathrm{GA}_{3}$ solution. An inhibition of germination of $V$. tucanorum seeds treated with growth regulators in darkness may account in part for a sort of "photoblastic" response, since the germinability of cold-stored seeds kept under white light and treated with growth regulators was similar to the non-treated seeds after three weeks (table 1). The germinability was insensitive to light in seeds treated with $\mathrm{GA}_{3}+\mathrm{CEPA}$, as well as in seeds stored at $25^{\circ} \mathrm{C}$ and imbibed in the CEPA solution (table 1). The effects of the $7^{\circ} \mathrm{C}$ and $25^{\circ} \mathrm{C}$ storage temperatures were similar to each other, both under white light and in darkness, except for seeds germinated in darkness and soaked in the CEPA solution, in which the germinability of seeds stored at $7^{\circ} \mathrm{C}$ was partially inhibited (table 1 ). It is known that the storage temperature can affect seed germination, as exemplified by Lamium amplexicaule $\mathrm{L}$. whose seeds remained non-dormant after 12 weeks of storage at $15 / 30{ }^{\circ} \mathrm{C}$, whereas those stored at $5{ }^{\circ} \mathrm{C}$ for 12 weeks entered conditional dormancy (Baskin \& Baskin 2001). Dormant seeds of Eugenia uvalha Cambess. stored for 60 and 90 days under refrigeration $\left(13 \pm 2{ }^{\circ} \mathrm{C}\right)$ showed a higher germinability and emergence rate than seeds stored at room temperature, whereas the latter was more effective than cold storage after 30 days (Scalon et al. 2004). Thus, considering that the storage time and temperature can modify the dormancy status of the seed, more research is required to test the response of $V$. tucanorum to storage since the relatively short storage time used (14 days), as well as the lack of dormancy of the seed batch, do not allow any general conclusion to be made about the effect of the storage temperature

Table 1. Effect of growth promoters on the germination after 7 and 21 days in white light and darkness of Vochysia tucanorum seeds stored for two weeks at the temperatures of $7{ }^{\circ} \mathrm{C}$ and $25^{\circ} \mathrm{C}$. Capital letters: vertical comparisons; small letters: horizontal comparisons (Tukey test, $\alpha=0.05)$. $(\mathrm{W}=$ distilled water control; GA = gibberellic acid; $\mathrm{CEPA}=$ 2-chloroethylphosphonic acid).

\begin{tabular}{|c|c|c|c|c|c|}
\hline \multirow{2}{*}{ Temperature } & \multirow{2}{*}{ Luminosity } & $\mathrm{W}$ & GA & CEPA & $\mathrm{GA}+\mathrm{CEPA}$ \\
\hline & & \multicolumn{4}{|c|}{ Germination (\%) after 7 days } \\
\hline \multirow{2}{*}{$7{ }^{\circ} \mathrm{C}$} & White light & $2.5 \mathrm{Ab}$ & $1.2 \mathrm{Ab}$ & $87.5 \mathrm{Aa}$ & $97.5 \mathrm{Aa}$ \\
\hline & Darkness & $0.0 \mathrm{Ac}$ & $0.0 \mathrm{Ac}$ & $30.0 \mathrm{Bb}$ & 88.7Aa \\
\hline \multirow{2}{*}{$25^{\circ} \mathrm{C}$} & White light & $0.0 \mathrm{Ac}$ & $0.0 \mathrm{Ac}$ & $82.5 \mathrm{Ab}$ & $97.5 \mathrm{Aa}$ \\
\hline & Darkness & $0.0 \mathrm{Ac}$ & $1.2 \mathrm{Ac}$ & $67.5 \mathrm{Ab}$ & 88.7Aa \\
\hline \multicolumn{6}{|c|}{ Germination (\%) after 14 days } \\
\hline \multirow{2}{*}{$7^{\circ} \mathrm{C}$} & White light & $91.2 \mathrm{Aa}$ & $95.0 \mathrm{Aa}$ & $98.7 \mathrm{Aa}$ & $100.0 \mathrm{Aa}$ \\
\hline & Darkness & $95.0 \mathrm{Aa}$ & $37.5 \mathrm{Bc}$ & $68.7 \mathrm{Bb}$ & $93.7 \mathrm{Aa}$ \\
\hline \multirow{3}{*}{$25^{\circ} \mathrm{C}$} & White light & 83.7Aa & $95.0 \mathrm{Aa}$ & $97.5 \mathrm{Aa}$ & $100.0 \mathrm{Aa}$ \\
\hline & Darkness & 88.7Aa & $20.0 \mathrm{Bb}$ & $97.5 \mathrm{Aa}$ & $100.0 \mathrm{Aa}$ \\
\hline & & \multicolumn{4}{|c|}{ Germination (\%) after 21 days } \\
\hline \multirow{2}{*}{$7^{\circ} \mathrm{C}$} & White light & $91.2 \mathrm{Aa}$ & $96.2 \mathrm{Aa}$ & $98.7 \mathrm{Aa}$ & $100.0 \mathrm{Aa}$ \\
\hline & Darkness & $98.7 \mathrm{Aa}$ & $50.0 \mathrm{Bb}$ & $68.7 \mathrm{Bb}$ & 3.7Aa \\
\hline \multirow{2}{*}{$25^{\circ} \mathrm{C}$} & White light & 83.7Aa & $95.0 \mathrm{Aa}$ & $97.5 \mathrm{Aa}$ & $100.0 \mathrm{Aa}$ \\
\hline & Darkness & $98.7 \mathrm{Aa}$ & $30.0 \mathrm{Bb}$ & $97.5 \mathrm{Aa}$ & $100.0 \mathrm{Aa}$ \\
\hline
\end{tabular}


on the germination of the species. Kepczynski et al. (1996), testing the responsiveness of Amaranthus retroflexus L. seeds to ethephon and gibberellic acid, reported that only at $30^{\circ} \mathrm{C}$ ethephon was efficient in promoting the germination of dormant seeds, whereas at lower temperatures its effect was markedly reduced. Those results suggest that the sensitivity of the seeds to ethylene decreases with decreasing temperature. A question remains whether cold storage could also affect the sensitivity of the $V$. tucanorum seeds to ethylene, as suggested by the present work.

Comparing the response of the Vochysia tucanorum seeds to the growth regulators, this work shows that the germinabilities after three weeks were similar for the treatments kept under white light, with the exception of the seeds stored at $25{ }^{\circ} \mathrm{C}$ and soaked in CEPA $+\mathrm{GA}_{3}$, in which the germinability was higher as compared to the distilled water control (table 1). For seeds germinated in darkness, the response to the growth regulators depended upon the storage temperature. The final germination of cold stored seeds was partially inhibited both in CEPA and $\mathrm{GA}_{3}$ treatments as compared to the distilled water control and CEPA $+\mathrm{GA}_{3}$, whereas the germinability of seeds stored at $25^{\circ} \mathrm{C}$ was inhibited only in $\mathrm{GA}_{3}$ treatment (table 1). The effect of CEPA $+\mathrm{GA}_{3}$ was more pronounced (maximum germination) one week after the start of the germination trials irrespective of the light conditions and storage temperature (table 1). The germination of seeds treated with CEPA was also advanced compared to the distilled water control, although to a lesser extent than that for the mixture CEPA $+\mathrm{GA}_{3}$. These results suggest an interaction of ethylene and gibberellins in improving the germination rate of Vochysia tucanorum seeds, as reported for Xanthium strumarium L. (Esashi et al. 1975) and Rumex crispus L. (Samimy \& Khan 1983). The soaking of V. tucanorum seeds in $\mathrm{GA}_{3}$ only had no effect on germination after 7 days (table 1). The concentration of the $\mathrm{GA}_{3}$ used in this work can account for the inability of this hormone in promoting the germination of $V$. tucanorum seeds. Kepczynski et al. (1996) reported that Amaranthus retroflexus seeds respond to $\mathrm{GA}_{3}$ concentrations as high as $1 \mathrm{mmol} \mathrm{L}^{-1}$, whereas the maximum response to CEPA can occur at a concentration of $0.001 \mathrm{mmol} \mathrm{L}^{-1}$. Bernardes et al. (2008) recommend a $\mathrm{GA}_{3}$ concentration of $c a .1 \mathrm{mmol} \mathrm{L}^{-1}$ for promoting the highest emergence percentage of Caryocar brasiliense Cambess. seedlings, with the germination decreasing at both higher and lower concentrations. Thus, higher concentrations of $\mathrm{GA}_{3}$ must be tested in order to assess the effect of that plant hormone on the germination of $V$. tucanorum seeds.
The use of CEPA can improve the germination rate of non dormant Vochysia tucanorum seeds under white light, and the combination of CEPA and $\mathrm{GA}_{3}$ was able to decrease the time for germination under white light and darkness, suggesting a synergistic effect of the two growth regulators in accelerating the germination process in this species. Thus, the preliminary results shown in this paper indicate that ethylene can be involved in the control of germination of non dormant $V$. tucanorum seeds, although more experiments are needed in order to confirm that hypothesis.

\section{References}

ABELES, F.B. 1986. Role of ethylene in Lactuca sativa L. cv. Grand Rapids seed germination. Plant Physiology 81:780-787.

BARBOSA, A.R., YAMAMOTO, K. \& VÁLIO, I.F.M. 1999. Effect of light and temperature on germination and early growth of Vochysia tucanorum Mart., Vochysiaceae, in cerrado and forest soil under different radiation levels. Revista Brasileira de Botânica 22:275-280.

BASKIN, J.M. \& BASKIN, C.C. 2001. Seeds: ecology, biogeography and evolution of dormancy and germination. Academic Press, San Diego.

BASKIN, J.M. AND BASKIN, C.C. 2006. Effect of temperature during burial on dormant and non-dormant seeds of Lamium amplexicaule L. and ecological implications. Weed Research 24:333-339.

BERNARDES, T.G., NAVES, R.V., REZENDE, C.F.A., BORGES, J.D. \& CHAVES, L.J. 2008. Propagação sexuada do pequizeiro (Caryocar brasiliense Camb.) estimulada por ácido giberélico. Pesquisa Agropecuária Tropical 38:71-77.

BURDETT, A.N. \& VIDAVER, W.E. 1971. Synergistic action of ethylene with gibberellin or red light in germinating lettuce seeds. Plant Physiology 48:656-657.

COSTA, A.A. \& ARAUJO, G.M. 2001. Comparação da vegetação arbórea de Cerradão e de Cerrado na Reserva do Panga, Uberlandia, Minas Gerais. Acta Botanica Brasilica 15:63-72.

ESASHI, Y., HATA, Y. \& KATOH, H. 1975. Germination of cocklebur seeds: interaction between gibberellic acid, benzyladenine, thiourea, $\mathrm{KNO}_{3}$ and gaseous factors. Australian Journal of Plant Physiology 2:569-579.

GANDOLFI, S., LEITÃO FILHO, H.F. \& BEZERRA, C.L. 1995. Levantamento florístico e caráter sucessional das espécies arbustivo-arbóreas de uma floresta mesófila semidecídua no Município de Guarulhos, SP. Revista Brasileira de Biologia 55:753-767.

HILHORST, H.W.M. \& KARSSEN, C.M. 1988. Dual effect of light on the gibberellin- and nitrate-stimulated seed germination of Sisymbrium officinale and Arabidopsis thaliana. Plant Physiology 86:591-597. 
KEPCZYNSKI, J., CORBINEAU, F. \& CÔME, D. 1996. Responsiveness of Amaranthus retroflexus seeds to ethephon, 1-aminocyclopropane 1-carboxylic acid and gibberellic acid in relation to temperature and dormancy. Plant Growth Regulation 20:259-265.

KUCERA, B., COHN, M.A. \& LEUBNER-METZGER, G. 2005. Plant hormone interactions during seed dormancy release and germination. Seed Science Research 15: 281-307.

MATILLA, A.J. \& MATILLA-VÁZQUEZ, M.A. 2008. Involvement of ethylene in seed dormancy. Plant Science 175:87-97.

MENDONÇA, R.C., FELFILI, J.M., WALTER, B.M.T., SILVA JÚNIOR, M.C., REZENDE, A.V., FILGUEIRAS, T.S. \& NOGUEIRA, P.E. 1998. Flora vascular do cerrado. In Cerrado: ambiente e flora. (S.M. SANO \& S.P. Almeida, eds.). Embrapa - Centro de Pesquisa Agropecuária dos Cerrados, Planaltina, p.287-556.

MITTERMEIER, R.A., MYERS, N. \& MITTERMEIER, C.G. 1999. Hotspots earth 's biologically richest and most endangered terrestrial ecoregions. Cemex/Conservation International, Washington.
MORAES, D.M. \& LOPES. N.F. 1998. Germinação e vigor de sementes de coentro (Coriandrum sativum L.) submetidas a reguladores de crescimento vegetal. Revista Brasileira de Sementes 20:93-99.

NASCIMENTO, M.T. \& SADDI, N. 1992. Structure and floristic composition in an area of cerrado in Cuiabá - MT, Brazil. Revista Brasileira de Botânica 15:47-55.

PEREIRA, E.B.C., PEREIRA, A.V., MELO, J.T., SOUSASILVA, J.C. \& FALEIRO, F.G. 2004a. Quebra da dormência de sementes de araticum. Boletim de Pesquisa e Desenvolvimento 137. Embrapa Cerrados, Planaltina.

PEREIRA, A.V., PEREIRA, E.B.C., SILVA, D.B., GOMES, A.C. \& SOUZA-SILVA, J.C. 2004b. Quebra da dormência de sementes de pequi. Boletim de Pesquisa e Desenvolvimento 136. Embrapa Cerrados, Planaltina.

SAMIMY, C. \& KHAN, A.A. 1983. Secondary dormancy, growth regulators effects and embryo growth potential in curly dock (Rumex crispus) seeds. Weed Science 31:153-158.

SCALON, S.P.Q., SCALON-FILHO, H.E. \& RIGONI, M.R. 2004. Armazenamento e germinação de sementes de uvaia (Eugenia uvalha Cambess). Ciência e Agrotecnologia 28:1228-1234. 
